\title{
The Effect of Human Resources Management Information System on Employees' Career Planning
}

\author{
Rony Susalit ${ }^{1, *}$ \\ ${ }^{1}$ Universitas Pendidikan Indonesia \\ *Corresponding author. Email: ronysusalit@ymail.com
}

\begin{abstract}
One effort to encourage employees' progress is by providing opportunities for employees to plan their own careers. The role of career development is needed for the continuity of the organization in achieving the expected results for the achievement of organizational goals in providing fulfillment of employee needs to develop competence, productivity and knowledge as well as broader authority and responsibilities from the scope of work in accordance with the position mandated by the organization. Career development must still consider all potential candidates using transparent measurement tools and it needs the right data to be taken into consideration. For this reason, appropriate information about staffing is needed to support employee career development. Management Information System is an integrated application to do all transaction processing in an organization including providing information support and data processing for management and decision-making functions. It includes all management systems in the company, including human resource management. Human Resources Management Information System or Human Resources Information System is a form of intersection between the fields of human resource management and the science of information and communication technology systems.
\end{abstract}

Keywords: Human Resources Management Information System, Employees' Career Planning.

\section{INTRODUCTION}

\subsection{Background}

In the current era of globalization, the development of science and technology is growing very well. Sources of information about science and technology are very fast and accurate. Indonesia, an archipelagic country which is quite far from one island to another, has a lot of natural and human resources which are in need of science and technology to support the development of the company equally. The most appropriate science and technology for the development of an organization is the information system.

A management information system is an information system that, in addition to doing all the transaction processing necessary for an organization, also provides information and processing support for management and decision-making functions. The information system is also very influential on the leader because he/she is faced with certain changes. Management information systems include all management systems in the company, including human resource management.

Human resource information systems or Human Resources Information System is a form of intersection between the fields of human resource management and information technology. This system combines human resource management as a discipline that mainly applies the information technology field to human resource management activities, such as planning, and compiles a data processing system in a series of standardized steps and summarized in the application of enterprise resource planning. However, not all companies implement this system. One of their reasons is their lack of knowledge regarding the development of human resource management information systems.

One effort to encourage the employees' progress is by providing opportunities for employees to plan their careers which ultimately lead to a career development for themselves. The role of career development is needed for the continuity of the organization in achieving the expected results for the achievement of 
desires in providing fulfillment of employee needs to develop both in career and broader knowledge about the scope of work. Employees will have the willingness to contribute if the organization can meet their needs. Thus, they will feel satisfied and work enthusiasm will arise.

\subsection{Formulation of the problem}

Based on the phenomena occurred, the formulation of the problem that were examined and analyzed in this study include:

- How is the implementation of the personnel information system in the organization?

- How is the implementation of employee career planning in the organization?

- To what extent does the implementation of the staffing information system affect employee career planning?

\subsection{Research Purpose \& Objectives}

The purpose of the research was to gain a broader scientific knowledge about the field of scientific management of human resources, especially human resource information systems used by organizations as a career planning tool.

The objectives of this research include:

- To find out the implementation of staffing information systems in the organization.

- To find out the implementation of employee career planning in organizations.

- To determine the effect of the implementation of staffing information systems on employee career planning in organizations.

\subsection{Human Resource Management}

The term management in today's society is not a new term or problem. Management comes from the word "to manage" which means managing the activities of a group of people in order to achieve the goals set.

Management in general is often referred to as a process for completing work through other people. This definition implies that management is a science and art that studies how to achieve organizational goals through the management of others to carry out various jobs required. This is in line with what is expressed by [1]:

"Management is the process of planning, organizing, directing and supervising the efforts of the members of the organization and the use of other organizational resources in order to achieve the stated organizational goals"
Management manages not only human resources but also material, capital and other factors of production. But after all, human resources are one of the most important factors of production that must be owned by every organization, so the consequence of all of them is the need for better management of human resources in order to obtain a meaningful contribution to the progress of the organization or company. Definition of human resource management according to [2] is:

"... a planning, organizing, directing, coordinating, implementing and supervising the procurement, development, remuneration, integration, maintenance, and separation of the workforce in order to achieve organizational goals"

Basically, a good human resource management must cover all management functions and operational functions [3], namely:

- Managerial functions which include: planning; organizing; directing; controlling.

- Operational functions which include: procurement of labor; development; compensation; integration; maintenance; termination.

\subsection{Human Resources Information System}

The definition of a human resource information system is stated by [4] as follows:

"Human Resource Information System (SISDM) is a systematic procedure of collecting, storing, maintaining, attracting, and validating data needed by an organization regarding human resources, personnel activities, and characteristics of its organizational units"

Reference [4] mentions that the character of human resource information systems must be designed to provide information, namely:

- On time, managers must have access to update information that has a timeline when the information is presented so that the decisionmaking process can be carried out properly.

- Accurate, managers must be able to depend on the accuracy of the information provided, meet a high level of accuracy, free from misleading notions, material errors, and be reliable by the user.

- In short, managers can absorb a lot of information needed in certain situations.

- Relevant, managers must get the information needed in certain situations and be connected with the intended use.

- Complete, the manager must obtain complete and uninterrupted information covering all aspects related to the usability of the information. 
Reference [4] states that career planning is a career development carried out to meet the needs of skilled and capable workforce to recruit workers, select, place employees and then evaluate the workforce results.

Career planning is not only beneficial for employees personally but also profitable for the company. Career planning enables companies to develop and place employees in positions that match their interests, needs, and career goals. On the other hand, career development is a fulfillment. Thus, the career development program aims to develop a balance between employee potential and company needs.

\subsection{Framework}

The mind framework underlying research related to human resource management with human resource information systems and planning Managing human resources requires information, as revealed by [5] that "Management of human resources depends on information". This is in line with the opinion put forward by [4] that "Managers and human resources departments require very large detailed information". Thus, to facilitate the management of human resources, a data processing system was formed namely recording employee activities.

The use of Human Resources Information Systems can be useful for other system applications because this system relates to all company employees as drivers of a company's performance. Human resource information systems are created to collect and maintain data that explains human resources, convert that data into information, and report that information to users. Implementation of an appropriate Human Resources Information System is expected to determine the accuracy of the data sources and inputs needed. The accuracy of the data depends on the quality of information used to support the preparation of the program, one of which is a career planning program for a company's employees.

Human resource information systems have an important role in preparing human resources effectively and efficiently through the availability of human resources information that is fast, complete, and accurate. Human resource information systems can provide several benefits, including:

- Information Technology Systems enable the human resources department to play an active role in the strategic planning of the organization.

- The human resources department can take a global perspective on the supply and development needs of human resources to be interpreted in a more effective manner.

- Human resource departments can benefit from direct access to external data sources that contain important information for the preparation of human resource strategies.

- Planning and management of human resources will be more targeted, more proportional, and more objective.

The relationship between the application of human resource information systems with career planning is supported by several opinions of experts such as:

- According to [6], a human resource information system is a system that supports management to facilitate the decision-making process which includes planning, receiving, placing, training, and developing and maintaining company resources or members.

- According to [7], human resource information systems can support planning with information for labor supply and forecast human resource demand.

The relationship between the application of a human resource information system program with manager's decisions in employee career planning is an inseparable unit.

From the research factors above, the hypothesis that can be drawn on the influence of human resource information systems on manager decision making in employee career planning is as follows:

"If the Human Resource Information System is implemented according to procedures, employee career planning will run well and correctly".

\section{METHODS}

\subsection{Descriptive \& Verification Methods}

The research method used in this research was descriptive method, which is carried out by collecting, then compiling the data so as to provide a systematic picture, then analyzed and drawn conclusions that can be used as a means for companies in the future.

\subsection{Data collection technique}

A questionnaire is said to be valid if the questions on the questionnaire are able to reveal something that will be measured by the questionnaire. Thus, all questionnaire items used to measure variables, namely human resource information systems and career planning, were tested for validity. The validity value of each question item can be seen in the corrected itemtotal correlation value of each question item. With $r$ table for 50 respondents of 0.279 , then based on the SPSS calculation, it was known that all variable item correlations were greater than $r$ table $(0.279)$ then the instrument was declared valid. In reliability testing using SPSS, the method that were used is the same as 
the validity testing step because the two outputs simultaneously appear.

\section{RESULTS AND DISCUSSION}

\subsection{Validity \& Reliability Test}

The validity value of each statement item can be seen in the Corrected item - Total Correlation value of each statement item. The number of respondents was as many as 50 people. Then based on the calculation of SPSS correlation coefficient (r) it is known that all the correlations of variable Human Resource Information System were greater than $r$ table or 0.279 then the instrument was declared valid. Likewise, for the variable Career Planning, if the correlation item variable Career Planning was greater than $r$ table or greater than 0.279 then the instrument was declared valid. The following is the validity test results using the number of respondents as many as 50 people and questionnaire statement items with a total of 20 statements processed by SPSS. The SPSS output for validity test of Human Resource Information Systems variable can be seen in Table 1 and for Validity test of Career Planning variable can be seen in Table 2 .

Table 1. Test the Validity of Human Resource Information Systems

\begin{tabular}{|l|l|l|l|}
\hline Statement & RCount & RTable & Information \\
\hline 1 & 0.280 & .279 & Valid \\
\hline 2 & 0.301 & .279 & Valid \\
\hline 3 & 0.536 & .279 & Valid \\
\hline 4 & 0.549 & .279 & Valid \\
\hline 5 & 0.615 & .279 & Valid \\
\hline 6 & .651 & .279 & Valid \\
\hline 7 & 0.611 & .279 & Valid \\
\hline 8 & 0.316 & .279 & Valid \\
\hline 9 & 0.322 & .279 & Valid \\
\hline 10 & .289 & .279 & Valid \\
\hline
\end{tabular}

Table 2. Test the Validity of Career Planning

\begin{tabular}{|l|l|l|l|}
\hline Statement & RCount & RTable & Information \\
\hline 1 & .374 & .279 & Valid \\
\hline 2 & .451 & .279 & Valid \\
\hline 3 & 0.464 & .279 & Valid \\
\hline 4 & 0.285 & .279 & Valid \\
\hline 5 & 0.305 & .279 & Valid \\
\hline 6 & .361 & .279 & Valid \\
\hline 7 & .457 & .279 & Valid \\
\hline 8 & .308 & .279 & Valid \\
\hline 9 & 0.395 & .279 & Valid \\
\hline 10 & 0,600 & .279 & Valid \\
\hline
\end{tabular}

In the Corrected item Total Correlation column each statement item has a value of more than 0.279 so that all statement items can be said to be valid.

In reliability testing using SPSS, the lag that is run is the same as the validity testing step, because both outputs simultaneously appear. Reliability of a variable construct is said to be good if it has a Cronbach's alpha value> 0.60 . Table 3 shows the results of the reliability test using the SPSS program for Human Resource Information Systems variable and Table 4 for Career Planning variable.

Table 3. Criteria for Reliability Tests for Human Resource Information System Variables

\begin{tabular}{|l|c|c|}
\hline \multicolumn{3}{|c|}{ Reliability Statistics } \\
\hline $\begin{array}{c}\text { Cronbach's } \\
\text { Alpha }\end{array}$ & $\begin{array}{c}\text { Cronbach's Alpha Based on } \\
\text { Standardized Items }\end{array}$ & $\begin{array}{c}\text { Nof } \\
\text { Items }\end{array}$ \\
\hline, 785 &, 771 & 10 \\
\hline
\end{tabular}

Table 4. Variable Reliability Test Criteria Employee Career Planning

\begin{tabular}{|c|c|c|}
\hline \multicolumn{3}{|c|}{ Reliability Statistics } \\
\hline $\begin{array}{c}\text { Cronbach's } \\
\text { Alpha }\end{array}$ & $\begin{array}{c}\text { Cronbach's Alpha Based on } \\
\text { Standardized Items }\end{array}$ & $\begin{array}{c}\text { N of } \\
\text { Items }\end{array}$ \\
\hline, 737 &, 736 & 10 \\
\hline
\end{tabular}

At Cronbach's Alpha value> 0.60, which is .771 and 0.736 , thus all items of a statement can be stated reliable.

\subsection{Analysis of the Effect of Human Resources Information Systems on Employee Career Planning}

To find out the relationship between Human Resources Information Systems and Employee Career Planning, a correlation test is needed. Correlation analysis is used to measure the relationship between the independent variable and the variable. Table 5 shows the result of Spearman Rank correlation coefficient analysis using the SPSS program.

Table 5. Calculation of the Spearman Rank Correlation Coefficient of Human Resources Information System (HRIS) Variables and Employee Career Planning (ECP) Variables

\begin{tabular}{|c|c|c|c|c|}
\hline \multicolumn{5}{|c|}{ Correlations } \\
\hline & & & AV HRIS & $A V E C P$ \\
\hline \multirow{6}{*}{$\begin{array}{l}\text { Spearman's } \\
\text { rho }\end{array}$} & \multirow{3}{*}{$\begin{array}{c}A V \\
H R I S\end{array}$} & $\begin{array}{c}\text { Correlation } \\
\text { Coefficient }\end{array}$ & 1,000 &, $623(* *)$ \\
\hline & & Sig. (1-tailed) & . &, 000 \\
\hline & & $N$ & 50 & 50 \\
\hline & \multirow{3}{*}{$\begin{array}{c}A V \\
E C P\end{array}$} & $\begin{array}{l}\text { Correlation } \\
\text { Coefficient }\end{array}$ &, $623(* *)$ & 1,000 \\
\hline & & Sig. (1-tailed) &, 000 & \\
\hline & & $N$ & 50 & 50 \\
\hline
\end{tabular}

Correlation is significant at the 0.01 level (1-tailed).

Based on the calculation of the Spearman Rank correlation, a rs of 0.623 is obtained. Because the value of $r$ is between $0,600-0,799$, the relationship between the Human Resources Information System and Employee Career Planning can be said to be strong and unidirectional as presented in the Table 6 . 
Table 6. Interpretation of Correlation Coefficients

\begin{tabular}{|l|l|}
\hline \multicolumn{1}{|c|}{ Coefficient interval } & Relationship Level \\
\hline $0,000-0,199$ & Very weak \\
\hline $0,200-0,399$ & Weak \\
\hline $0,400-0,599$ & Strong enough \\
\hline $0,600-0,799$ & Strong \\
\hline $0,800-1,000$ & Very strong \\
\hline
\end{tabular}

To determine the magnitude of the effect of the use of Human Resources Information Systems Against Employee Career Planning, the calculation of the coefficient of determination is used using the (1).

$$
\begin{gathered}
c d=r s^{2} \times 100 \%=0,623^{2} \times 100 \% \\
=38,81 \%
\end{gathered}
$$

The magnitude of the influence of the use of Human Resources Information Systems Against Employee Career Planning is $38.81 \%$ and the remaining $61.19 \%$ is influenced by other factors not examined in this research. Based on the results from interviews with several respondents, they said that they liked the information presented by the division human resources regarding personnel data that is fast, easily accessible, complete and guaranteed confidentiality from outside parties.

\subsection{Hypothesis test}

To find out whether or not the hypothesis is accepted, a right-sided test was conducted, as for the formulation of the hypothesis as follows:

- H0: rs $\leq$ : means that the Human Resource Information System has no positive influence on Employee Career Planning.

- Ha: rs> 0: means that the Human Resource Information System has a positive influence on Employee Career Planning.

Compare $\mathrm{t}$ arithmetic with $\mathrm{t}$ table with the following criteria:

- If $\mathrm{t}$ arithmetic $\geq \mathrm{t}$ table, then $\mathrm{H} 0$ is rejected and $\mathrm{H} 1$ is accepted.

- If $\mathrm{t}$ arithmetic < table, then $\mathrm{H} 0$ is accepted and $\mathrm{H} 1$ is rejected.

This hypothesis used a significance level $(\alpha)$ of $5 \%$ (0.05) with a degree of freedom or degree of freedom (df). Where degrees of freedom (df) are:

$\mathrm{Df}=\mathrm{n}-(\mathrm{k}-1)$

$=50-2$

$=48$
To determine $\mathrm{t}$ arithmetic the (3) is used for determine t count and (4) is used for determine $t$ table.

$\mathrm{t}$ count $=\mathrm{r} \sqrt{ }(\mathrm{n}-2) /\left(1-\mathrm{r}^{\wedge} 2\right)$

t count $=5,517$

$\mathrm{t}$ table $=\mathrm{t}(\alpha: \mathrm{df})$

t table $=(0,05: 48)$

Because there is no $\mathrm{df}=48$ in the table, it is searched through the following calculation:

Known:

$$
\begin{aligned}
& \mathrm{t}(0.05 ; 40)=1.684 \\
& \mathrm{t}(0,05 ; 60)=1,671
\end{aligned}
$$

Then for $\mathrm{df}=48$

$$
\begin{aligned}
8(1,671-x) & =12(x-1,684) \\
8 x-13,368 & =12 x-20,208 \\
8 x=12 x \quad & =20,208+13,368 \\
20 x & =33,576 \\
x & =1,678
\end{aligned}
$$

It is known that $\mathrm{x}=1.678$, then for $\mathrm{t}(0.05: 48)$ it is 1.678. From the above calculation, it can be seen that $t$ arithmetic $=5.517$ is greater than t table $=1.678$, which means $\mathrm{H} 0$ is rejected and $\mathrm{Ha}$ is accepted. In other words, the use of Human Resources Information Systems has a positive influence on Employee Career Planning. For more details, hypothesis testing is presented in Figure 1.

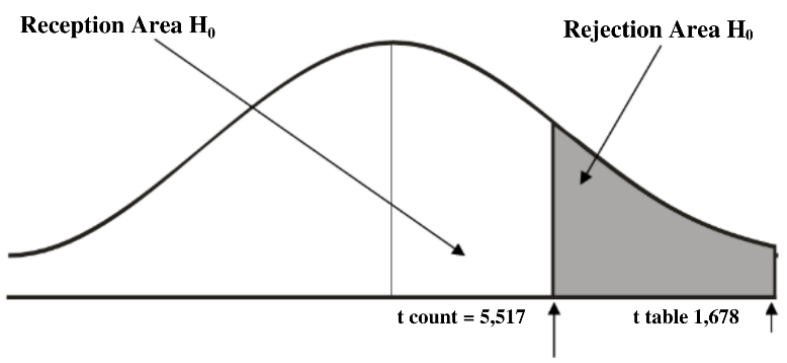

Figure 1. Test the Significance of Correlation Coefficients One-Party Test

Based on Figure 1, the ttable $=1.678$ and tcount $=$ 5.517 are in the rejection area H0. This means that the hypothesis proposed, "The Use of Human Resources Information Systems has a positive effect on Employee Career Planning", is acceptable. 


\section{CONCLUSIONS}

Human Resources Information System implemented in the organization was considered effective because it has the highest average value of each questionnaire submitted to respondents in the amount of 4.26 with an interval value of 4.20 - 5.00 which was very good. Based on the analysis of Rank Spearman (rs), which is intended to determine the closeness of the relationship between the use of Human Resources Information Systems for Employee Career Planning, it showed that there was a strong relationship. This was indicated by the value of 0.623 with the integral coefficient between 0,600 - 0,799. Based on the analysis of hypothesis testing using the $\mathrm{t}$ distribution, the results obtained $\mathrm{t}$ count $>\mathrm{t}$ table $=5.517>1.678$, thus $\mathrm{H} 0$ was rejected and Ha was accepted, meaning that the Human Resource Information System had a positive influence on Employee Career Planning. With the results of the coefficient of determination (CD) of $38.81 \%$ it can be concluded that Employee Career Planning was influenced by the Human Resources Information System by $38.81 \%$, while the remaining $61.19 \%$ is influenced by other variables not examined in this study.

\section{ACKNOWLEDGMENT}

This paper and the research behind would not have been possible without the exceptional support of all my supervisors. The enthusiasm, knowledge, and exacting attention to detail have been an inspiration and kept my work on track from my first encounter.

\section{REFERENCES}

[1] A.F. Stoner James, R.E. Freeman, and D.R. Gilbert, Management, Indonesian edition, Jakarta: PT. Intermedia, 1994

[2] A.P. Mangkunegara and A. Prabu, Human Resource Management, Jakarta: Rosda Karya, 2009.

[3] T.H. Handoko, Human Resource Management, Yogyakarta: BPFE-Yogyakarta, 2001.

[4] H. Simamora, Human Resource Management, Yogyakarta: YKPN, 2004.

[5] S.P. Siagian, Human Resources Management, Jakarta: Earth Literacy, 2007.

[6] Susanto, Management Information Systems, Yogyakarta: Lingga Jaya, 2005.

[7] Sihotang, Human Resource Management, Jakarta: Pradnya Paramita, 2007. 